\title{
Surveys of the bee (Hymenoptera: Apiformes) community in a Neotropical savanna using pan traps
}

\author{
Thaís Andrade Viana ${ }^{1,2,3}$ \& Anete Pedro Lourenço ${ }^{1,4}$ \\ 1 Universidade Federal dos Vales do Jequitinhonha e Mucuri (UFVJM), Faculdade de Ciências Biológicas e da Saúde (FCBS), \\ Departamento de Ciências Biológicas (DCBIO). Diamantina, MG, Brasil. \\ ${ }^{2}$ Universidade Federal de Viçosa (UFV), Departamento de Entomologia (DDE). Viçosa, MG, Brasil. \\ 3 ORCID: http://orcid.org/0000-0001-8794-9275. E-mail: thaistablito@yahoo.com.br \\ ${ }^{4}$ ORCID: http://orcid.org/0000-0001-6929-7277. E-mail: anete.lourenco@ufvjm.edu.br (corresponding author)
}

\begin{abstract}
Bee populations are declining because of various synergistic threats, and therefore bee survey and monitoring programs are needed. Several techniques have been developed to survey bees, but the most cost-effective and suitable methods to sample bees in several sites at the same time are passive approaches, such as methods involving colored pan traps (also known as Moericke or bowl traps). Several bee surveys using pan traps have been conducted in North America, Europe, and Australia, but only a few such surveys have been done in tropical regions. We used colored pan traps (blue, yellow, and white) to assess the bee community in the Brazilian savanna ecosystem in Rio Preto State Park. Sampling was conducted in October 2013 and March 2014 along permanent trails. We also characterized the local habitat of each trail, and then we compared bee abundance with habitat complexity. In total, 187 individual bees ( $n=15$ species) were collected, mainly using blue and white traps. Although we were not able to sample most species that were previously recorded in this park, the pan trap method can be used to survey and monitor bee assemblages in combination with another sampling method. Habitat complexity also affected the numbers of bees sampled using the pan traps, and more bees were collected at open sites.
\end{abstract}

Key-Words. Callonychium; Dialictus; Wild bees; Cerrado; South America.

\section{INTRODUCTION}

Declines in insect populations in natural and agricultural ecosystems have been increasingly studied in recent years (Potts et al., 2010). Of all insects, bees (Hymenoptera: Apiformes) are the most important pollinators. They play an important role in the pollination of most plants in their native environments, and are important pollinators of crop plants in agroecosystems. Hence, the need for surveys to understand and monitor the diversity and abundance of bees has increased (Imperatriz-Fonseca et al., 2007; Potts et al., 2010).

There are several methods that can be used to survey bees, but their efficacy depends on whether the purpose of the survey is to determine diversity patterns or to monitor bee abundance and species richness (Kremen et al., 1993; Roulston et al., 2007; Missa et al., 2009). Passive survey methods can be very valuable, as they allow for data to be collected simultaneously in several sites, allow for a high sampling effort, and avoid potential monitor skill bias (Cane et al., 2000; Westphal et al., 2008; Tuell \& Isaacs, 2009). Among the passive sur- vey methods, pan traps (also known as Moerick or bowl traps) are usually used to survey agricultural pests and other phytophagous insects (Evans \& Medler, 1967; Boiteau, 1983). However, pan traps can also be used to sample pollinators (Leong \& Trorp, 1999; Campbell \& Hanula, 2007; Gollan et al., 2011).

Pan traps consist of colored bowls (yellow, white, and blue are the most commonly used colors) that are usually placed on the ground. The traps are filled with water, with drops of detergent added to break the water surface tension, then winged insects can land in the bowls and drown (Dafni et al., 2005). A number of factors can affect the efficiency of bee surveys with pan traps, such as their color (Campbell \& Hanula, 2007; Tuell \& Isaacs, 2009; Gonçalves \& Oliveira, 2013; Buri et al., 2014; Heneberg \& Bogusch, 2014; Larsen et al., 2014; Moreira et al., 2016), the weather (Gonçalves et al., 2009), and local flora and habitat characteristics (Cane et al., 2000; Mayer, 2005; Roulston et al., 2007; Wilson et al., 2008; Morandin \& Kremen, 2013; Saunders \& Luck, 2013; Torné-Noguera et al., 2014; Landaverde-González et al., 2017; Prado 
et al., 2017). Habitat structure and complexity can affect the diversity and composition of terrestrial arthropod fauna (Lassau \& Hochuli, 2004, 2005, 2007; Lassau et al., 2005). Cavity-nesting bee population and orchid bee species richness responded positively to habitat complexity (Antonini et al., 2016; Lourenço et al., 2020).

Colored pan traps are commonly used in North America and Europe (e.g., Campbell \& Hanula, 2007; Baum \& Wallen, 2011; Dirrigl, 2012; Devigne \& De Biseau, 2014; Fortel et al., 2014; Joshi et al., 2015), but this methodology is still underused in Neotropical regions, especially in the Brazilian savanna (e.g., Krug \& Alves-dosSantos, 2008; Gonçalves \& Oliveira, 2013; Moreira et al., 2016; Prado et al., 2017). The Brazilian savanna ecosystem (also known as Cerrado) is the second largest biome in Brazil (Klink \& Machado, 2005), and is one of the world's most important biodiversity hotspots (Myers et al., 2000). However, relatively little is known about the bee fauna of this ecosystem (Azevedo et al., 2008; Andena et al., 2009). Here, we used pan traps to assess bee species in a Brazilian savanna ecosystem in Rio Preto State Park (state of Minas Gerais). The pan traps were placed in permanent trails previously established for animal and plant biodiversity surveys. Due to the variation in habitat structure among the sampling trails, we also investigated the effect of habitat composition on bee abundance. Our main questions were: (i) Are colored pan traps effective for assessing the bee species in a Brazilian savanna ecosystem?; (ii) Are some bee species exclusively captured by pan traps?; (iii) Do bees show preference for a specific trap color?; and (iv) Does the habitat structure around the traps affect the samplings?

\section{MATERIAL AND METHODS}

\section{Study area}

This study was conducted in Rio Preto State Park (Parque Estadual do Rio Preto, referred to as PERP hereafter) which covers approximately 12,000 ha, and is located in the southern part of the Espinhaço Mountain Range, in the municipality of São Gonçalo do Rio Preto, State of Minas Gerais, southeastern Brazil. The climate of the region is tropical (Cwb in the Köppen climate classification system), with mild wet summers (October to April) and cold dry winters (June to August). Annual mean precipitation ranges from 1,250 to $1,550 \mathrm{~mm}$, the mean annual temperature is approximately $18-19^{\circ} \mathrm{C}$, and the mean annual relative humidity is $75.6 \%$ (Neves et al., 2005). The park was created in 1994, mainly to protect the headwaters of the Rio Preto river and the local biodiversity (IEF, 2004).

The PERP has typical characteristics of the Cerrado biome. The predominant vegetation formations are grasslands and Brazilian savanna, as well as semideciduous forests, which occur mainly along streams and rivers. The vegetation type of the sampling sites (Figs. S1 and S2) include grassland (known locally as campo rupestre, rocky fields) with shrubs and herbaceous species (e.g., points 4.1 and 4.2, Fig. S2), as well as small trees and scattered shrubs characteristic of the Brazilian savanna ecosystem (known as Cerrado strictu sensu) (e.g., points 2.1-2.5, Fig. S2), and vegetation typical of gallery forests along streams and rivers, where the canopy was much denser and higher, with the tallest trees reaching heights of approximately 10-15 m (e.g., point 3.5, Fig. S2).

\section{Field surveys}

The bees were sampled along five trails that were located approximately $1 \mathrm{~km}$ apart (these trails were established by the ComCerrado Network to survey and monitor the PERP flora and fauna). We sampled along $250 \mathrm{~m}$ in each trail, with sections spaced $50 \mathrm{~m}$ apart. One point from each beginning of the section was used to place the traps (geographic coordinates and altitude of the trails and points can be found in Table S1). Five sets of three pan traps were placed on the ground every $50 \mathrm{~m}$, adding 15 pan traps per trail (Fig. S1). During all period of this study, a total of 150 pan traps were placed in PERP. Each point consisted of three plastic bowls, which had $15 \mathrm{~cm}$ diameter (ForFest Ind. De Descartáveis LTDA. PFAM-15) of different colors (yellow, blue, and white), as suggested by Moreira et al. (2016). The pan traps contained water and some drops of neutral detergent.

The traps were placed in the morning (7:00-8:00 h), and the insects were collected after 24 hours. All points along each trail were sampled simultaneously in a single day, and for the following five days ( $1^{\text {st }}-5^{\text {th }}$ of October 2013; $18^{\text {th }}-22^{\text {nd }}$ of March 2014). There was no change in the weather to impair the bee collection in the sampling periods. The insects were organized by pan trap color and transferred to vials containing $70 \%$ ethanol. The specimens were dried, pinned, separated by morphospecies, and identified according to Silveira et al. (2002). The species were identified or confirmed by the specialist Dr. Fernando Silveira. The specimens were deposited at the Taxonomic Collection of the Federal University of Minas Gerais and the Collection of Bees at the Federal University of Jequitinhonha and Mucuri Valleys.

\section{Habitat characterization}

Habitat complexity was scored using the visual method proposed by Coops \& Catling (1997). This method has often been used to measure and predict the effect of habitat complexity on terrestrial arthropod assemblies, including bees (Lassau \& Hochuli, 2004, 2005, 2007; Lassau et al., 2005; Antonini et al., 2016; Lourenço et al., 2020). We used scores of 0 (low cover/content) to 3 (high cover/content) for each of the following criteria: \% of tree canopy cover, \% of shrub cover, $\%$ of ground herbage cover, \% covered by logs, rocks, debris, etc., and moisture in the soil (Coops \& Catling, 1997; for more details on the parameters used, see Table S2). Each point of the five trails (Figs. S2 and S3) was characterized and scored for each category, and for habitat complexity (the sum of each category score; Coops \& Catling, 1997). 


\section{Data analyses}

Species diversity and evenness were calculated using the indexes of Shannon-Wiener $\left(\mathrm{H}^{\prime}\right)$ and Pielou $\left(\mathrm{J}^{\prime}\right)$, respectively, using PAST 2.16 software (Hammer et al., 2001). The differences in the Shannon-Wiener indexes were evaluated using t-tests (significance set at $p<0.05$ ). Species accumulation curves were constructed for each sampling period (October and March) using EstimateS 9.1.0 software (Colwell, 2013). Differences in bee abundance (number of bees per species) between months and at different trails were evaluated using $G$ tests (significance set at $p<0.05$ ) using BioEstat 5.0 software (Ayres et al., 2007). Differences of bee richness between months (collection data for each trail as a sample) were verified using Mann-Whitney test (significance set at $\mathrm{p}<0.05$ ) according to PAST 3.26 software.

To evaluate the completeness of the pan traps in surveying bee species richness in PERP, we followed the methods developed by McCravy et al. (2016). Hence, we calculated Chao 1 to estimate bee species richness, and estimated the additional sample size needed to achieve 80,90 and $100 \%$ of Chao 1 estimates using the Excelsheet calculator at the Ecological Archives E090-073-S1 (Chao et al., 2009). Chao 1 richness estimator was chosen because of small sample sizes in this study ( $n=5$, using collection data for each trail as a sample) and possible dependence among the samples.

Spearman rank correlations were conducted to test the correlations between bee abundance (in both October and March) and total habitat complexity score or individual variable scores (tree canopy cover, shrub canopy cover, ground herbage cover, cover of logs, rocks, and debris, and soil moisture) for each sampling point (data are provided in Table S3).

\section{RESULTS}

In total, 187 bees were collected, comprising 15 species belonging to three families (Andrenidae, Apidae, and Halictidae). Nine and 12 species were recorded in October 2013 and March 2014, respectively (Table 1). No significant difference in species richness was observed between October and March (Mann-Whitney, p > 0.05). The high dominance of a few species contributed to low evenness in both sampling periods (October, $\mathrm{J}^{\prime}=0.683$; March, J' $=0.520$, Table 1). No significant difference in species diversity was observed between October $\left(H^{\prime}=1.501\right)$ and March $\left(H^{\prime}=1.291\right.$; t-test, $\left.p=0.536\right)$. The species accumulation curves did not stabilize (Fig. 1), and according to the Chao 1 estimator, approximately $69 \%$ and $75 \%$ of the bee species were collected in October and March, respectively (Table 2 ). To reach the expected bee richness estimated by Chao 1 (100\%), 133 (October) and 541 (March) more individuals should have been captured (Table 2). Thus, more samplings are needed to achieve the asymptotic bee species richness at this site, and it is estimated that a 3.6-fold greater sampling effort should be made for a complete survey based on the Chao 1 estimate (Table 2). Of the total 187 bees, 37 were captured in
October 2013, and 150 in March 2014, and this difference was significant $(G=26.09$, D.F. $=14, p=0.025$, Table 1).

The four most abundant species were Callonychium sp.

(> 50\% in both years), followed by Dialictus sp. 1 ,

Table 1. Species and number of individuals of bees captured in pan traps in the Rio Preto State Park, Minas Gerais, Brazil, during five consecutive days in 0ctober 2013 and March 2014.

\begin{tabular}{|c|c|c|c|c|c|}
\hline \multirow{2}{*}{\multicolumn{2}{|c|}{ Species }} & \multicolumn{2}{|c|}{ October 2013} & \multicolumn{2}{|c|}{ March 2014} \\
\hline & & $\mathbf{N}$ & $\%$ & N & $\%$ \\
\hline Andrenidae & Callonychium sp. & 21 & 56.8 & 98 & 65.3 \\
\hline \multirow[t]{8}{*}{ Apidae } & Bombus pauloensis Friese, 1913 & 1 & 2.7 & 0 & 0 \\
\hline & Ceratina (Crewella) sp. 1 & 2 & 5.4 & 2 & 1.3 \\
\hline & Ceratina (Crewella) sp. 2 & 2 & 5.4 & 1 & 0.7 \\
\hline & Ceratina (Crewella) sp. 3 & 0 & 0 & 1 & 0.7 \\
\hline & Ceratina (Crewella) sp. 4 & 3 & 8.1 & 5 & 3.3 \\
\hline & Ceratina (Crewella) sp. 5 & 1 & 2.7 & 4 & 2.7 \\
\hline & Paratrigona subnuda Moure, 1947 & 0 & 0 & 1 & 0.7 \\
\hline & Tetragonisca angustula (Latreille, 1811) & 0 & 0 & 2 & 1.3 \\
\hline \multirow[t]{6}{*}{ Halictidae } & Augochlora sp. 1 & 1 & 2.7 & 0 & 0 \\
\hline & Augochlora sp. 2 & 1 & 2.7 & 0 & 0 \\
\hline & Dialictus sp. 1 & 5 & 13.5 & 18 & 12 \\
\hline & Dialictus sp. 2 & 0 & 0 & 3 & 2 \\
\hline & Dialictus sp. 3 & 0 & 0 & 14 & 9.3 \\
\hline & Thectochlora alaris (Vachal, 1904) & 0 & 0 & 1 & 0.7 \\
\hline \multicolumn{2}{|c|}{ Total of individuals } & 37 & 100 & 150 & 100 \\
\hline \multicolumn{2}{|c|}{ Total of species } & \multicolumn{2}{|c|}{9} & \multicolumn{2}{|c|}{12} \\
\hline \multicolumn{2}{|c|}{ Shannon ( $\left.\mathrm{H}^{\prime}\right)$} & \multicolumn{2}{|c|}{1.501} & \multicolumn{2}{|c|}{1.291} \\
\hline \multicolumn{2}{|l|}{ Piellou - $\left(J^{\prime}\right)$} & \multicolumn{2}{|c|}{0.683} & \multicolumn{2}{|c|}{0.520} \\
\hline
\end{tabular}

Table 2. Abundance, species richness, Chao 1 estimates, and additional sample sizes needed to achieve 80,90 and $100 \%$ of the Chao 1 estimate for bees captured by pan traps in the Rio Preto State Park, Minas Gerais, Brazil, during five consecutive days in October 2013 and March 2014.

\begin{tabular}{lccc}
\hline \multicolumn{1}{c}{ Parameters } & October 2013 & March 2014 \\
\hline Number of bees collected & & 37 & 150 \\
Observed species richness & & 9 & 12 \\
Chao 1 estimate & $80 \%$ & $16(0.43 \mathrm{x})$ & $33(0.22 \mathrm{x})$ \\
\hline & & 13 & 16 \\
Number of additional bees that should be collected & $90 \%$ & $42(1.1 \mathrm{x})$ & $137(0.91 \mathrm{x})$ \\
to a given Chao 1 percentage (fold increase) & $100 \%$ & $133(3.6 \mathrm{x})$ & $541(3.6 \mathrm{x})$ \\
\hline
\end{tabular}

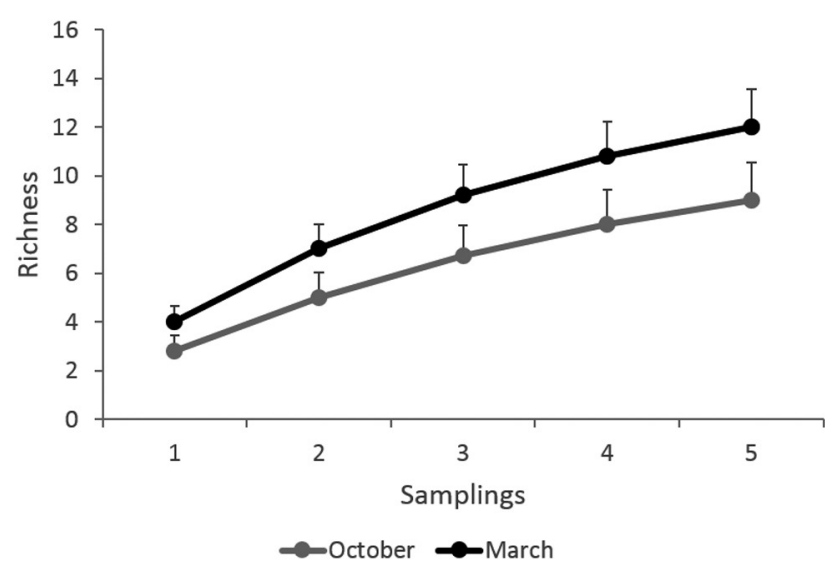

Figure 1. Species accumulation curves (mean + SD) and richness estimator Chao 1 values for the bees captured by pan traps in the Rio Preto State Park, Minas Gerais, Brazil, during five consecutive days of samplings in 0ctober 2013 and March 2014. 
Dialictus sp. 3, and Ceratina sp. 4 (Table 1). Callonychium sp. was captured by pan traps of all three colors, but mainly by blue (51\%) and white (45\%) pan traps, whereas Dialictus spp. did not show a preference. In general, $48.7 \%$ of bees were captured by blue traps, followed by white (38.7\%), and yellow (12.7\%) traps. Three species were captured only by yellow traps (Paratrigona subnuda, Tetragonisca angustula, and Thectochlora alaris), whereas blue and white traps did not capture exclusive species.

Regarding bee richness and abundance along the trails, trail $5(n=5)$ and trail $1(n=8)$ showed the highest richness in October 2013 and March 2014, respectively (Fig. 2A). Trail 3 showed the highest abundance in both sampling periods $(n=23$ in October 2013 and $n=86$ in March 2014, Fig. 2B). In October 2013, bee abundance in trail 3 was higher than in trail 5 (G = 32.60; D.F. = 14; $\mathrm{p}=0.0033$ ), whereas in March 2014, bee abundance in trail 3 was higher than in trail $1(G=61.77$; D.F. $=14$; $\mathrm{p}<0.0001)$, trail $2(\mathrm{G}=102.61$; D.F. $=14 ; \mathrm{p}<0.0001)$, and trail 5 ( $G=26.24$; D.F. $=14 ; p=0.024$, Fig. 2B).

Due to the habitat complexity differences among the points in the five trails, we scored each point for habitat complexity (Table S3), and then we evaluated the relationship between habitat complexity and bee abundance. A negative correlation was observed between bee abundance and habitat complexity (Spearman correlation: $r=-0.507 ; n=50 ; p<0.0001$, Fig. 3A). Comparisons between bee abundance and each habitat category separately showed that bee abundance was negatively correlated with tree canopy cover (Spearman correlation: $r=-0.461 ; n=50 ; p<0.0001$, Fig. 3B), and with percent cover by logs, rocks, and debris (Spearman correlation: $r=-0.481 ; n=50 ; p<0.0001$, Fig. 3E). Positive correlations were observed between bee abundance and ground herb cover (Spearman correlation: $r=0.337 ; n=50$; $p=0.017$, Fig. 3D). No significant correlation was found between bee abundance and shrub canopy (Fig. 3C), nor soil moisture (Fig. 3F). In general, bee abundance was lower in points with more tree canopy cover and larger amounts of debris. On the other hand, open points with more ground herb cover were associated with higher bee abundance.

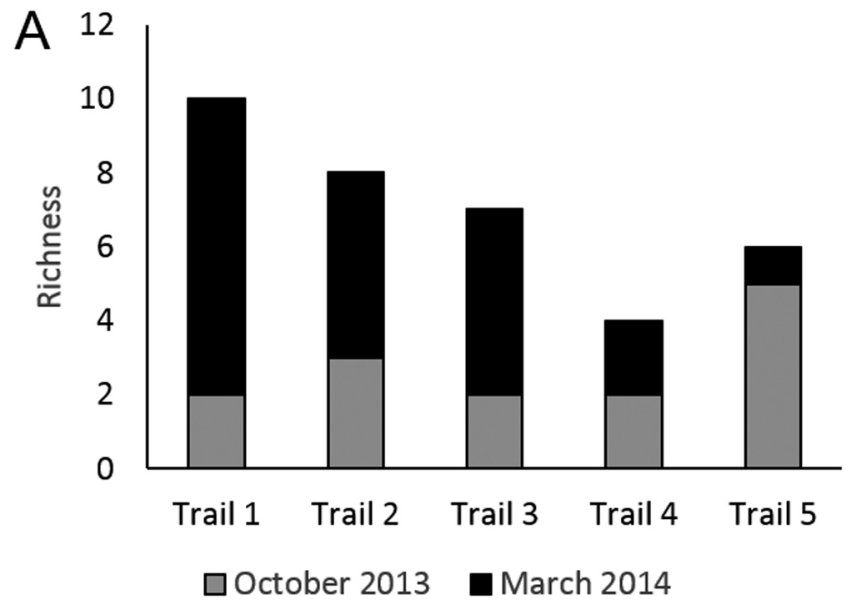

\section{DISCUSSION}

\section{Bees collected by pan traps}

Our surveys using pan-traps to sample bees in PERP indicate a low abundance (187 individuals) and richness (15 species) of bees when compared to a study previously conducted in the area (Azevedo et al., 2008). Azevedo et al. (2008) registered 140 species in the PERP using entomological nets intensive sampling efforts (which included low numbers of surveys from October 2004 to May 2006, with $\geq 40$ hours of collections in dry and wet seasons), and listed seven more bee species previously deposited in Bee Collections and other published studies. Thus, using pan traps, we recorded only $10 \%$ of the bee species/morphotypes known to exist in PERP. Previous studies comparing different sampling methodologies that were applied simultaneously showed that pan traps were able to capture 44\% (Krug \& Alves-dos-Santos, 2008) and 58\% (Popic et al., 2013) of the total species found in a given area.

The efficiency of the pan traps in capturing bees depends mainly on the number of pan traps used (Shapiro et al., 2014), the distance and distribution of the pan traps (Droege et al., 2010), the color of the pan traps (Heneberg \& Bogusch, 2014; Moreira et al., 2016), the habitat structure of the area where the traps are set (Landaverde-González et al., 2017), and the amount of flowering plants and the colors of the flowers near the pan traps (Morandin \& Kremen, 2013). Moreover, conducting samplings in more than one season will result in more species being sampled, due to variations in bee abundance and richness throughout the year (Shapiro et al., 2014). Here, we surveyed the bees along pre-established trails that are used to survey and monitor the PERP animal and plant communities (ComCerrado Network), and therefore we could not choose the best locations to place the pan traps. However, in future, we could use a higher number of pan traps, as increasing the number of pan traps along a transect increases the number of individuals and species sampled (Shapiro et al., 2014). In addition, future surveys could also include the dry season, as done by Azevedo et al. (2008).

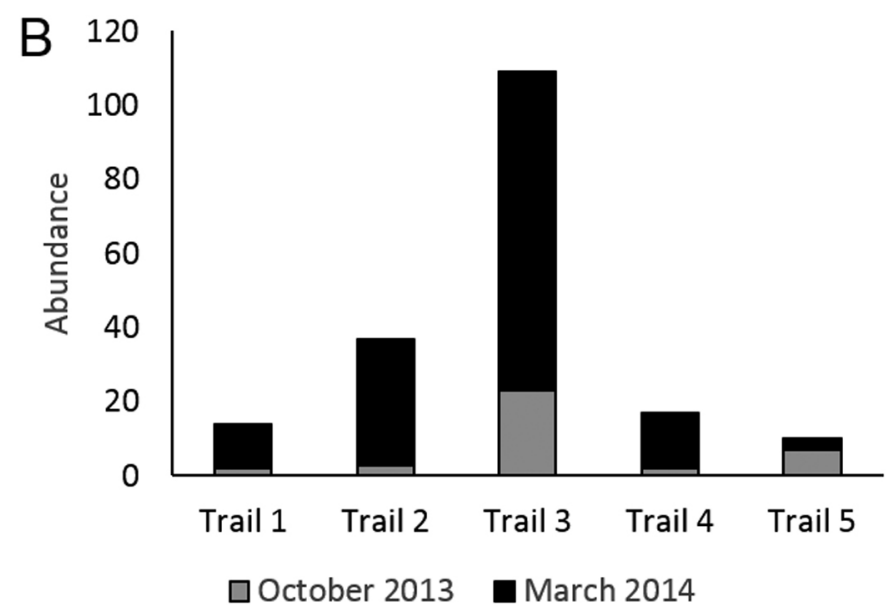

Figure 2. Species richness (A) and abundance (B) of bees collected by pan traps in each trail (1-5) during five consecutive days in 0ctober 2013 and March 2014 at Rio Preto State Park, Minas Gerais, Brazil. 
Other strategies can also be used to improve bee abundance and richness, but it is important to clearly define the purpose of the samplings, i.e., whether the aim is to obtain a complete list of the bees occurring in the area, or to estimate changes in species through time (Shapiro et al., 2014). To obtain exhaustive surveys of the bee species and abundance in a given area, it is important to use active sampling methodologies, and the pan trap method should be used as a complementary method (Cane et al., 2000; Geroff et al., 2014; Moreira et al., 2016). Thus, for a rapid assessment and monitoring of the bee richness and diversity, pan traps can be used, but for more extensive data collection, this could be combined with other methods such as entomological nets, and Malaise and scent traps.

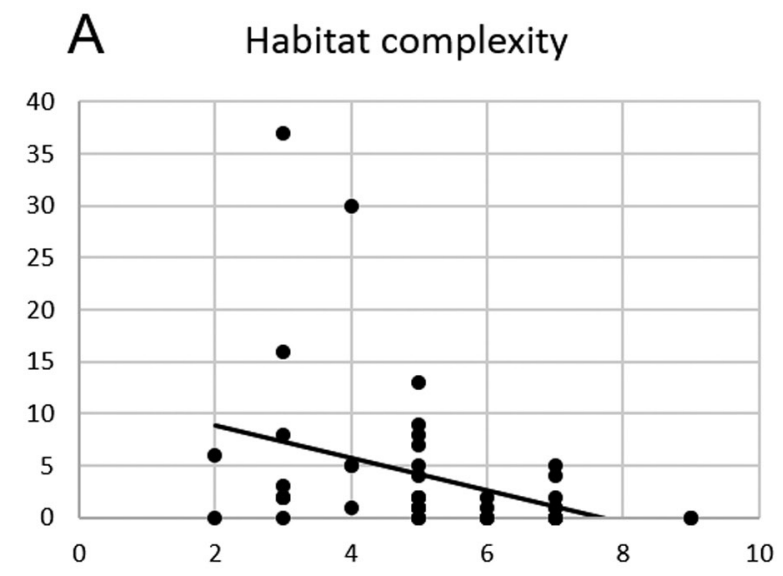

B Tree canopy cover

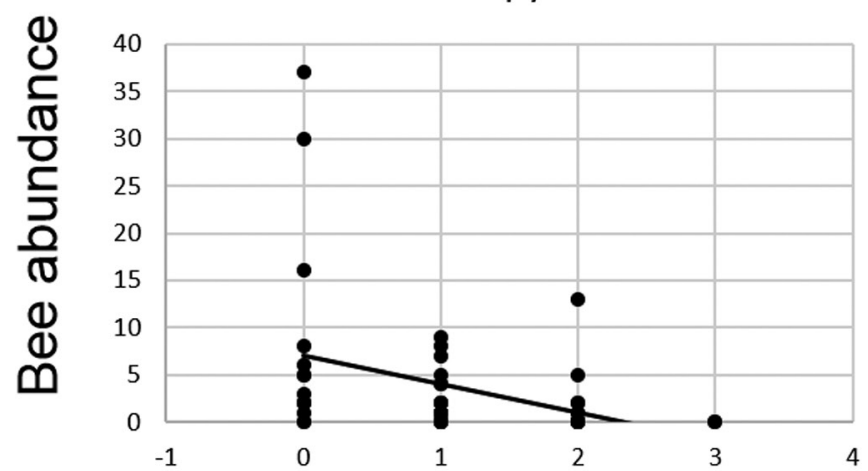

C Shrub canopy cover

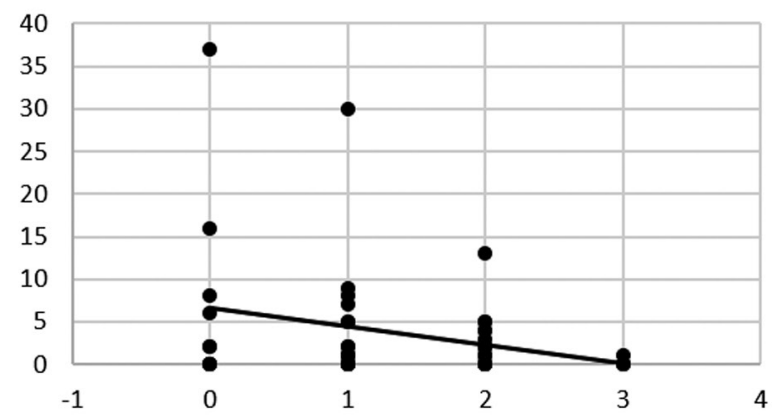

Habitat score

\section{Bee species exclusively collected by pan traps}

Previous studies demonstrated that pan traps can be used to collect species that are not frequently collected by active methodologies, mainly of Halictidae family, such as Dialictus, and other small bees of Andrenidae family (Callonychium and Anthrenoides) (Krug \& Alvesdos-Santos, 2008; Tuell \& Isaacs, 2009; Baum \& Wallen, 2011; Gonçalves \& Oliveira, 2013). In fact, the bees we sampled using pan traps were placed in the genera expected to be sampled using this methodology. However, we did not observe bees in any genera that had not been previously recorded in PERP (Azevedo et al., 2008). In this study, we were unable to identify some of the bee species due to the lack of taxonomic revision in some gen-

\section{Ground herb cover}

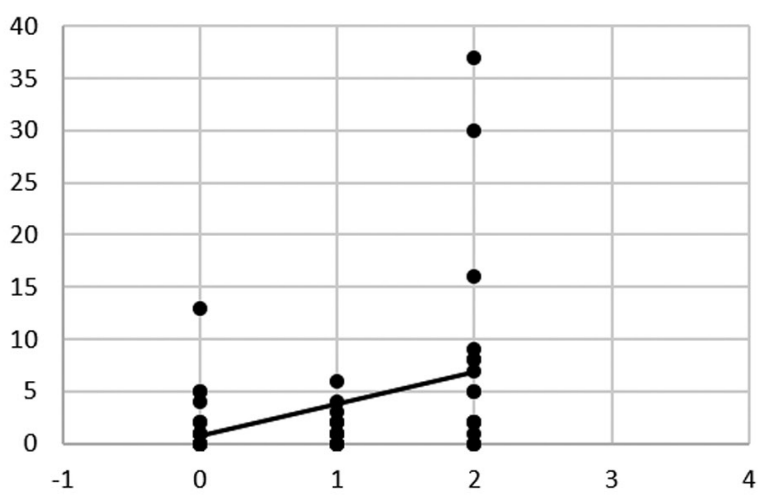

E Logs/rocks/debris amount
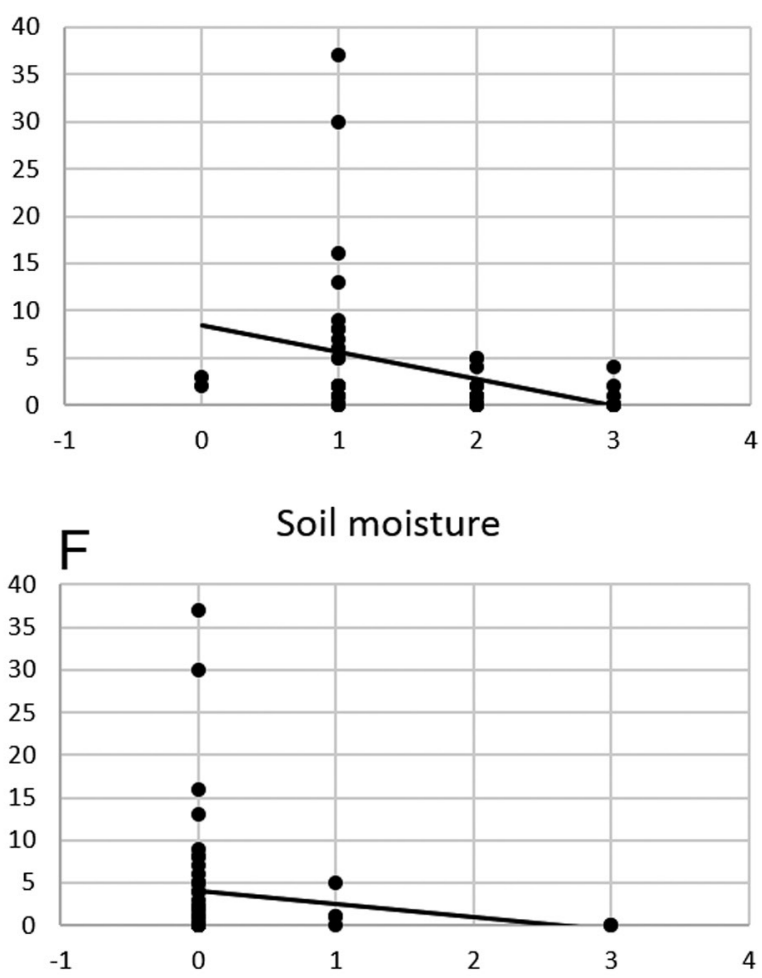

Habitat score

Figure 3. Bee abundance in relation to the habitat complexity (A) and to each habitat score (varying 0 to 3): tree canopy cover (B), shrub canopy cover (C), ground herb cover (D), amount of logs, rocks and debris (E), and soil moisture (F). 
era. As such, it was not possible to directly compare the results of our study and those of Azevedo et al. (2008).

The species Callonychium sp. was the most abundant, both in October 2013 and March 2014. There are only two Callonychium species that have been recorded in Brazil (Moure et al., 2012), and neither of these occur in Minas Gerais. Callonychium brasiliense (Ducke, 1907) occurs in Pernambuco, Ceará and Maranhão, and C. petuniae Cure \& Wittmann, 1990 occurs in Paraná, Rio Grande do Sul and Santa Catarina (Moure et al., 2012; Milet-Pinheiro et al., 2013). Our study took place in Minas Gerais, and we collected in high abundance an undescribed species of Callonychium. This is likely the same Callonychium species as Callonychium sp. nov. 02 collected in PERP by Azevedo et al. (2008). The other Callonychium species recorded in the Espinhaço Mountain Range was collected in Bahia State (Azevedo et al., 2008).

\section{Pan trap color preference}

The combination of using different colored pan traps (yellow, blue, and white) is highly recommended (Gonçalves \& Oliveira, 2013; Buri et al., 2014; Button \& Elle, 2014; Rubene et al., 2015; Moreira et al., 2016), as there is a distinct preference for each color among bee species (e.g., Campbell \& Hanula, 2007; Tuell \& Isaacs, 2009; Larsen et al., 2014; Heneberg \& Bogusch, 2014). In general, Aculeata prefer yellow (e.g., Dirrigl, 2012; Vrdoljak \& Samways, 2012; Heneberg \& Bogusch, 2014), although there is no consensus of which color is the most attractive to the bees, and it may depend on the habitat (Saunders \& Luck, 2013).

In previous studies, the highest bee abundance and species richness were observed in blue traps when compared to yellow and white traps in savanna ecosystems in Brazil (Moreira et al., 2016) and other environments (Cane et al., 2000; Stephen \& Rao, 2005; Hall, 2018). The preference for white and blue pan traps in our study is mainly due to the preference of the most collected species, Callonychium sp.. Callonychium petuniae bees are oligolectic and have a high preference for petunia-purple color tones in Rio Grande do Sul (Wittmann et al., 1990). In contrast, C. brasiliense bees in Pernambuco were very abundant on Turnera hermannioides (Passifloraceae) flowers, which have cream-colored petals that gradually become yellowish toward the center of the flowers (Milet-Pinheiro et al., 2013). However, the flower preferences of the Callonychium sp. collected in this study have not yet been described.

\section{Effect of habitat structure on bees sampled using pan traps}

Bees were captured at lower rates when pan traps were placed in the shade under trees and thick vegetation (more shrubs), which may indicate that there are fewer bees in these environments, or that the bees may be in the canopy, or it may be that there are simply lower capture rates due to pan trap shading. Medium to largesized bee species forage primarily in the canopy (Bawa, 1990). In temperate regions, studies have shown that when pan traps are elevated into the canopy, the abundance of bees captured can be greater than those placed at ground level (Tuell \& Isaacs, 2009). However, the method involving aerial pan traps into the canopy has yet to be carried out in the tropics (Prado et al., 2017). Higher species richness and abundance of bees were also observed in open habitats compared to wooded habitats in a study using pan traps in Australia (Hall, 2018) and in other tropical regions (Prado et al., 2017). In open sites, the bees are able to see more easily the colored pan traps, as the absence of floral patches can make the traps more visible and attractive (Morandin \& Kremen, 2013). In our study, trail 3 had points with open areas (points 3.1 and 3.2), at which we collected most of the bees, as well as sites located very close to a permanent body of water, where wet soil can be a resource for bees to build their nests or to obtain salt (Nicolson, 2009). These characteristics seem to be ideal for sampling bees using colored pan traps.

We also found differences in bee abundance depending on the month, more bees were collected in March when compared to October. Efficiency of the colored pan traps may vary according to the availability of the floral resources, that is, the greater the floral availability, the lower the sampling efficiency (Cane et al., 2000; Mayer, 2005; Roulston et al., 2007; Wilson et al., 2008; Morandin \& Kremen, 2013). However, in spring-summer seasons in Brazilian savannas there are many flowering plants, and even more in March when compared to October (Eiten, 1972; Batalha et al., 1997), mainly as a result of high precipitation in the previous 3-4 months (NovemberFebruary). Thus, the low abundance of bees captured by pan traps in October could be a result of the low abundance of insects at this time of the year, as during this period the insects are starting to emerge from the winter period (June, July, and August).

\section{CONCLUSION}

Passive methods are the most convenient way to quickly assess and monitor bee abundance and diversity. Pan traps are an inexpensive survey method that can sample several locations at the same time, and also avoids the influence of potential collector skills bias. Thus, we suggest using a combination of the three pan trap colors (blue, yellow, and white), to increase the number of traps, and the time these traps are deployed in the field. We also suggest sampling bees in different periods of the year and in open areas. Furthermore, to improve thoroughness, we recommend using more than one sampling method to evaluate and monitor bee biodiversity (Cane et al., 2000). For example, Malaise traps could be used (McCravy et al., 2016), although this methodology is expensive, and only a few traps can be placed in the field. Further surveys using Malaise traps are needed to assess their efficiency for collecting bees in a Neotropical savanna ecosystem, because Malaise traps can sometimes 
be relatively ineffective (McCravy \& Ruholl, 2017). Traps designed to collect male bees of Euglossini may also be used (traps described by Cordeiro et al., 2019). Although these traps require scents to attract bees, they are not expensive, and work very well in Neotropical savanna ecosystems, even with the low abundance of these bees in these ecosystems (Viotti et al., 2013), and can therefore increase knowledge on bee richness of an area. For instance, we collected 596 Euglossini bees belonging to 12 species (with new records for the area) using this method in PERP during the same period of this study (paper in preparation). Regarding habitat complexity, we suggest placing the traps in open areas, as fewer bees were captured at wooded sites. However, to try to increase the sampling efficiency in wooded places, traps suspended in the trees could also be used.

\section{ACKNOWLEDGEMENTS}

We thank Priscila C.S. Araújo, André R.S. Garraffoni and Thiago A. Quintão for their assistance during the field samplings. We are grateful to Prof. Fernando Silveira of the Departamento de Zoologia, Universidade Federal de Minas Gerais, Belo Horizonte for the identification of the bees. We also thank the three anonymous reviewers for their insightful comments and suggestions. Fieldwork in the Rio Preto State Park - Parque Estadual do Rio Preto (PERP) was conducted under the authorization of the Instituto Estadual de Florestas (IEF) do Estado de Minas Gerais. This study was supported by MCTI-Rede ComCerrado and CNPq (563134/2010-0).

\section{REFERENCES}

Andena, S.R.; Nascimento, F.S.; Bispo, P.C.; Mechi, M.R.; Mateus, S. \& Bego, L.R. 2009. Bee communities (Hymenoptera: Anthophila) of the "Cerrado" ecosystem in São Paulo State, Brazil. Genetics and Molecular Research, 8(2): 766-774. DOI

Antonini, Y.; Silveira, R.A.; Oliveira, M.L.; Martins, C. \& Oliveira, R. 2016. Orchid bee fauna responds to habitat complexity on a savanna area (Cerrado) in Brazil. Sociobiology, 63(2): 819-825. D01

Ayres, M.; Ayres Junior, M.; Ayres, D.L. \& Santos, A.A. 2007. Bioestat-5.0: Aplicações estatísticas nas áreas das ciências bio-médicas. Belém, PA, Sociedade Civil Mamirauá/MCT-CNPQ. 364p. 1 CD-ROM

Azevedo, A.; Silveira, F.; Aguiar, C. \& Pereira, V. 2008. Fauna de abelhas (Hymenoptera, Apoidea) nos campos rupestres da Cadeia do Espinhaço (Minas Gerais e Bahia, Brasil): riqueza de espécies, padrões. Megadiversidade, 4(1-2): 154-181.

Batalha, M.A.; Aragaki, S. \& Mantovani, W. 1997. Variações fenológicas das espécies do cerrado em Emas (Pirassununga, SP). Acta Botanica Brasilica, 11:61-78.

Baum, K.A. \& Wallen, K.E. 2011. Potential bias in pan trapping as a function of floral abundance. Journal of the Kansas Entomological Society, 84(2): 155-159. D0I

Bawa, K.S. 1990. Plant-pollinator interactions in tropical rain forests. Annual Review of Ecology, Evolution, and Systematics, 21: 399-422. DOI

Boiteau, G. 1983. The arthropod community of potato fields in New Brunswick, 1979-1981. The Canadian Entomologist, 115(7): 847-853. D01
Buri, P.; Humbert, J.Y. \& Arlettaz, R. 2014. Promoting pollinating insects in intensive agricultural matrices: Field-scale experimental manipulation of hay-meadow mowing regimes and its effects on bees. PLOS ONE, 9(1): 1-8, e85635. DOI

Button, L. \& Elle, E. 2014. Wild bumble bees reduce pollination deficits in a crop mostly visited by managed honey bees. Agriculture, Ecosystems \& Environment, 197: 255-263. D0I

Campbell, J.W. \& Hanula, J.L. 2007. Efficiency of Malaise traps and colored pan traps for collecting flower visiting insects from three forested ecosystems. Journal of Insect Conservation, 11: 399-408. DOI

Cane, J.H.; Minckley, R.L. \& Kervin, L.J. 2000. Sampling Bees (Hymenoptera: Apiformes) for Pollinator Community Studies: Pitfalls of Pan-Trapping. Journal of the Kansas Entomological Society, 73: 225-231. Available at: http://www.jstor.org/stable/25085973.

Chao, A.; Colwell, R.K.; Lin, C.W. \& Gotelli, N.J. 2009. Sufficient sampling for asymptotic minimum species richness estimators. Ecology, 90(4): 1125-1133. D0I

Colwell, R.K. 2013. EstimateS, Version 9.1: Statistical Estimation of Species Richness and Shared Species from Samples (Software and User's Guide). Available at: http://viceroy.eeb.uconn.edu/estimates.

Coops, N.C. \& Catling, P.C. 1997. Predicting the complexity of habitat in forests from airborne videography for wildlife management. International Journal of Remote Sensing, 18(12): 2677-2682. DOI

Cordeiro, M.; Garraffoni, A.R.S. \& Lourenço, A.P. 2019. Rapid assessment of the orchid bee fauna (Hymenoptera: Apidae: Euglossini) in the vicinity of an urban Atlantic Forest remnant in São Paulo, Brazil, Brazilian Journal of Biology, 79: 149-151. DOI

Dafni, A.; Kevan, P.G. \& Husband, B.C. 2005. Practical pollination biology. Canada, Enviroquest Ltda. 590p.

Devigne, C. \& De Biseau, J.C. 2014. Urban ecology: comparison of the effectiveness of five traps commonly used to study the biodiversity of flying insects. Biodiversity, 5: 165-174.

Dirrigl, F.J. 2012. Effectiveness of Pan Trapping as a Rapid Bioinventory Method of Freshwater Shoreline Insects of Subtropical Texas. Southwestern Entomologist, 37: 133-139. D0I

Droege, S.; Tepedino, V.J.; LeBuhn, G.; Link, W.; Minckley, R.L.; Chen, Q. \& Conrad, C. 2010. Spatial patterns of bee captures in North American bowl trapping surveys. Insect Conservation and Diversity, 3(1): 15-23. D0I

Eiten, G. 1972. The cerrado vegetation of Brazil. The Botanical Review, 38: 201-341. DOI

Evans, D.A. \& Medler, J.T. 1967. Flight activity of the corn leaf aphid in Wisconsin as determined by yellow pan trap collections. Journal of Economic Entomology, 60(4): 1088-1091. DOI

Fortel, L.; Henry, M.; Guilbaud, L.; Guirao, A.L.; Kuhlmann, M.; Mouret, H.; Rollin, 0. \& Vaissière, B.E. 2014. Decreasing abundance, increasing diversity and changing structure of the wild bee community (Hymenoptera: Anthophila) along an urbanization gradient. PLOSONE, 9(8): e104679.DOI

Geroff, R.K.; Gibbs, J. \& McCravy, K.W. 2014. Assessing bee (Hymenoptera: Apoidea) diversity of an Illinois restored tallgrass prairie: methodology and conservation considerations. Journal of Insect Conservation, 18(5): 951-964. D0I

Gollan, J.R.; Ashcroft, M.B. \& Batley, M. 2011. Comparison of yellow and white pan traps in surveys of bee fauna in New South Wales, Australia (Hymenoptera: Apoidea: Anthophila). Austral Entomology, 50: 174-178. DOI

Gonçalves, R.B. \& Oliveira, P.S. 2013. Preliminary results of bowl trapping bees (Hymenoptera, Apoidea) in a southern Brazil forest fragment. Journal of Insect Biodiversity, 1(2): 1-9. DOI

Gonçalves, R.B.; Melo, G.A. \& Aguiar, A.J. 2009. A assembléia de abelhas (Hymenoptera, Apidae) de uma área restrita de campos naturais do 
Parque Estadual de Vila Velha, Paraná e comparações com áreas de campos e cerrado. Papéis Avulsos de Zoologia, São Paulo, 49(14): 163-181. D0I

Hall, M. 2018. Blue and yellow vane traps differ in their sampling effectiveness for wild bees in both open and wooded habitats. Agricultural and Forest Entomology, 1: 1-9. DOI

Hammer, Ø.; Harper, D.A.T. \& Ryan, P.D. 2001. PAST: Paleontological statistics software package for education and data analysis. Palaeontologia Electronica, 4: 1-9.

Heneberg, P. \& Bogusch, P. 2014. To enrich or not to enrich? Are there any benefits of using multiple colors of pan traps when sampling aculeate Hymenoptera? Journal of Insect Conservation, 18(6): 1123-1136. DOI

Imperatriz-Fonseca, V.; Saraiva, A.M. \& Gonçalves, L.A. 2007. Iniciativa brasileira de polinizadores e os avanços para a compreensão do papel dos polinizadores como produtores de serviços ambientais. Bioscience Journal, 23: 100-106.

Instituto Estadual de Florestas (IEF). 2004. Plano de Manejo do Parque Estadual do Rio Preto. Belo Horizonte, IEF. 24p.

Joshi, N.K.; Leslie, T.; Rajotte, E.G.; Kammerer, M.A.;Otieno, M. \& Biddinger, D.J. 2015. Comparative trapping efficiency to characterize bee abundance, diversity, and community composition in apple orchards. Annals of the Entomological Society of America, 108(5): 785-799. DOI

Klink, C.A. \& Machado, R.B. 2005. A conservação do Cerrado brasileiro. Megadiversidade, 1: 147-155.

Kremen, C.; Colwell, R.K.; Erwin, T.L.; Murphy, D.D.; Noss, R.A. \& Sanjayan, M.A. 1993. Terrestrial arthropod assemblages: their use in conservation planning. Conservation Biology, 7(4): 796-808. DOI

Krug, C. \& Alves-dos-Santos, I. 2008. 0 uso de diferentes métodos para amostragem da fauna de abelhas (Hymenoptera: Apoidea), um estudo em floresta ombrófila mista em Santa Catarina. Neotropical Entomology, 37(3): 265-278. D0I

Landaverde-González, P.; Quezada-Euán, J.J.G.; Theodorou, P.; Murray, T.E.; Husemann, M.; Ayala, R.; Moo-Valle, H.; Vandame, R. \& Paxton, R.J. 2017. Sweat bees on hot chillies: provision of pollination services by native bees in traditional slash-and-burn agriculture in the Yucatán Peninsula of tropical Mexico. Journal of Applied Ecology, 54(6): 1814-1824. https://besjournals. onlinelibrary.wiley.com/doi/pdfdirect/10.1111/1365-2664.12860.

Larsen, N.J.; Minor, M.A.; Cruickshank, R.H. \& Robertson, A.W. 2014. Optimising methods for collecting Hymenoptera, including parasitoids and Halictidae bees, in New Zealand apple orchards. Journal of AsiaPacific Entomology, 17(3): 375-381. D01

Lassau, S.A. \& Hochuli, D.F. 2004. Effects of habitat complexity on ant assemblages. Ecography, 27(2): 157-164. DOI

Lassau, S.A. \& Hochuli, D.F. 2005. Wasp community responses to habitat complexity in Sydney sandstone forests. Austral Ecology, 30: 179-187. DOI

Lassau, S.A. \& Hochuli, D.F. 2007. Associations between wasp communities and forest structure: do strong local patterns hold across landscapes? Austral Ecology, 32(6): 656-662. DOI

Lassau, S.A.; Hochuli, D.F.; Cassis, G. \& Reid, C.A.M. 2005. Effects of habitat complexity on forest beetle diversity: do functional groups respond consistently? Diversity and Distributions, 11:73-82. D0I

Leong, J. \& Thorp, R.W. 1999. Colour-coded sampling: the pan trap colour preferences of oligolectic and nonoligolectic bees associated with a vernal pool plant. Ecological Entomology, 24(3): 329-335. D0I

Lourenço, A.P.; Santos, A.P.M.; Checon, H.H.; Costa, M.R.; \& Assis Júnior, S.L. 2020. Cavity-nesting bee communities in areas with different levels of vegetation disturbance. Studies on Neotropical Fauna and Environment, 1-13. DOI

Mayer, C. 2005. Does grazing influence bee diversity: molecules, organisms, ecosystems. In: International Symposium on Tropical Biology, $5^{\circ}$. Proceedings. Boston, MA, Springer. p. 173-179. D0I
McCravy, K.W. \& Ruholl, J.D. 2017. Bee (Hymenoptera: Apoidea) diversity and sampling methodology in a Midwestern USA Deciduous Forest. Insects, 8(3): 81 . DOI

McCravy, K.W.; Geroff, R.K. \& Gibbs, J. 2016. Tallgrass Prairie Malaise trap sampling efficiency for bees (Hymenoptera: Apoidea) in a restored tallgrass prairie, Florida Entomologist, 99: 321-323. D0I

Milet-Pinheiro, P.; de Andrade Penante, D.C. \& Schlindwein, C. 2013. Low legitimate pollen flow in distylic Turnera hermannioides (Passifloraceae) and its consequences on fruit and seed set. Flora-Morphology, Distribution, Functional Ecology of Plants, 208(10-12): 570-578. D0I

Missa, 0.; Basset, Y.; Alonso, A.; Miller, S.E.; Curletti, G.; De Meyer, M.; Eardley, N.; Mansell, M.W. \& Wagner, T. 2009. Monitoring arthropods in a tropical landscape: relative effects of sampling methods and habitat types on trap catches. Journal of Insect Conservation, 13(1): 103-118. D0I

Morandin, L.A. \& Kremen, C. 2013. Hedgerow restoration promotes pollinator populations and exports native bees to adjacent fields. Ecological Applications, 23(4): 829-839. DOI

Moreira, E.F.; Santos, R.L.S.; Penna, U.L.; Angel-Coca, C.; de Oliveira, F.F. \& Viana, B.F. 2016. Are pan traps colors complementary to sample community of potential pollinator insects? Journal of Insect Conservation, 20:583-596. DOI

Moure, J.S.; Urban, D. \& Melo, G.A.R. 2012. Catalogue of Bees (Hymenoptera, Apoidea) in the Neotropical Region - online version. Available at: http:// www.moure.cria.org.br/catalogue. Access in: 31/07/2017.

Myers, N.; Mittermeier, R.A. \& Mittermeier, C.G. 2000. Biodiversity hotspots for conservation priorities. Nature, 403: 853-858. DOI

Neves, S.C.N.; Abreu, P.A.A. \& Fraga, L.M.S. 2005. Fisiografia. In: Silva, A.C.; Pedreira, L.C.V.S.F. \& Abreu, P.A.A. (Eds.). Serra do Espinhaço Meridional: Paisagens e ambientes. Belo Horizonte, 0 Lutador. p. 47-58.

Nicolson, S.W. 2009. Water homeostasis in bees, with the emphasis on sociality. Journal of Experimental Biology, 212(3): 429-434. D01

Popic, T.J.; Davila, Y.C. \& Wardle, G.M. 2013. Evaluation of common methods for sampling invertebrate pollinator assemblages: net sampling outperform pan traps. PLOS ONE, 8(6): e66665. DOI

Potts, S.G.; Biesmeijer, J.C.; Kremen, C.; Neumann, P.; Schweiger, 0. \& Kunin, W.E. 2010. Global pollinator declines: trends, impacts and drivers. Trends in Ecology \& Evolution, 25: 345-353. D01

Prado, S.G.; Ngo, H.T.; Florez, J.A. \& Colazzo, J.A. 2017. Sampling bees in tropical forests and agroecosystems: a review. Journal of Insect Conservation, 21: 753. DOI

Roulston, T.A.H.; Smith, S.A. \& Brewster, A.L. 2007. A comparison of pan trap and intensive net sampling techniques for documenting a bee (Hymenoptera: Apiformes) fauna. Journal of the Kansas Entomological Society, 80: 179-181. D0I

Rubene, D.; Schroeder, M. \& Ranius, T. 2015. Diversity patterns of wild bees and wasps in managed boreal forests: effects of spatial structure, local habitat and surrounding landscape. Biological Conservation, 184: 201-208. DOI

Saunders, M.E. \& Luck, G.W. 2013. Pan trap catches of pollinator insects vary with habitat. Australian Journal of Entomology, 52(2): 106-113. DOI

Shapiro, L.H.; Tepedino, V.J. \& Minckley, R.L. 2014. Bowling for bees: optimal sample number for "bee bowl" sampling transects. Journal of insect conservation, 18(6): 1105-1113. DOI

Silveira, F.A.; Melo, G.A.R. \& Almeida, E.A.B. 2002. Abelhas brasileiras: sistemática e identificação. Belo Horizonte: F.A. Almeida. 253p.

Stephen, W.P. \& Rao, S. 2005. Unscented Color Traps for Non-Apis Bees (Hymenoptera: Apiformes). Journal of the Kansas Entomological Society, 78: 373-380. DOI

Torné-Noguera, A.; Rodrigo, A.; Arnan, X.; Osorio, S.; Barril-Graells, H.; da Rocha-Filho, L.C. \& Bosch, J. 2014. Determinants of spatial distribution 
in a bee community: nesting resources, flower resources, and body size. PLOS ONE, 9: e97255. DOI

Tuell, J.K. \& Isaacs, R. 2009. Elevated pan traps to monitor bees in flowering crop canopies. Entomologia Experimentalis et Applicata, 131(1): 93-98. DOI

Viotti, M.A.; Moura, F.R. \& Lourenço, A.P. 2013. Species Diversity and Temporal Variation of the Orchid-Bee Fauna (Hymenoptera, Apidae) in a Conservation Gradient of a Rocky Field Area in the Espinhaço Range, State of Minas Gerais, Southeastern Brazil. Neotropical Entomology, 42: 565-575.

Vrdoljak, S.M. \& Samways, M.J. 2012. Optimising coloured pan traps to survey flower visiting insects. Journal of Insect Conservation, 16(3): 345-354. D0l

Westphal, C.; Bommarco, R.; Carré, G.; Lamborn, E.; Morison, N.; Petanidou, T.; Potts, S.G.; Roberts, S.P.M.; Szentgyorgyi, H.; Tscheulin, T.; Vaissière,
B.E.; Woyciechowski, M.; Biesmeijer, J.C.; Kenin, W.E.; Sttele, J. \& Steffan-Dewenter, I. 2008. Measuring bee diversity in different European habitats and biogeographical regions. Ecological Monographs, 78(4): 653-671. DOI

Wilson, J.S.; Griswold, T. \& Messinger, 0.J. 2008. Sampling bee communities (Hymenoptera: Apiformes) in a desert landscape: are pan traps sufficient? Journal of the Kansas Entomological Society, 81: 288-300. DOI

Wittmann, D.; Radtke, R.; Cure, J.R. \& Schifino-Wittmann, M.T. 1990. Coevolved reproductive strategies in the oligolectic bee Callonychium petuniae (Apoidea, Andrenidae) and three purple flowered Petunia species (Solanaceae) in southern Brazil. Journal of Zoological Systematics and Evolutionary Research, 28(3): 157-165. DOI 
SUPPLEMENTARY MATERIAL

Table S1. Geographic coordinates and altitude of the studied sites.

\begin{tabular}{|c|c|c|c|}
\hline \multicolumn{2}{|c|}{ Trails/Sites } & \multirow{2}{*}{$\begin{array}{c}\text { Geographic coordinates } \\
18^{\circ} 04^{\prime} 21.9^{\prime \prime} \mathrm{S}, 43^{\circ} 20^{\prime} 48.2^{\prime \prime} \mathrm{W}\end{array}$} & \multirow{2}{*}{$\begin{array}{c}\text { Altitude } \\
911 \mathrm{~m}\end{array}$} \\
\hline 1 & 1 & & \\
\hline & 2 & $18^{\circ} 04^{\prime} 21.8^{\prime \prime} \mathrm{S}, 43^{\circ} 20^{\prime} 49.5^{\prime \prime} \mathrm{W}$ & $918 \mathrm{~m}$ \\
\hline & 3 & $18^{\circ} 04^{\prime} 22.6^{\prime \prime} \mathrm{S}, 43^{\circ} 20^{\prime} 50.8^{\prime \prime} \mathrm{W}$ & $916 \mathrm{~m}$ \\
\hline & 4 & $18^{\circ} 04^{\prime} 23.8^{\prime \prime} \mathrm{S}, 43^{\circ} 20^{\prime} 51.2^{\prime \prime} \mathrm{W}$ & $917 \mathrm{~m}$ \\
\hline & 5 & $18^{\circ} 04^{\prime} 25.55^{\prime \prime} \mathrm{S}, 43^{\circ} 20^{\prime} 51.9^{\prime \prime} \mathrm{W}$ & $902 \mathrm{~m}$ \\
\hline \multirow[t]{5}{*}{2} & 1 & $18^{\circ} 04^{\prime} 54.3^{\prime \prime} \mathrm{S}, 43^{\circ} 20^{\prime} 46.7^{\prime \prime} \mathrm{W}$ & $918 \mathrm{~m}$ \\
\hline & 2 & $18^{\circ} 04^{\prime} 54.5^{\prime \prime} \mathrm{S}, 43^{\circ} 20^{\prime} 48.0^{\prime \prime} \mathrm{W}$ & $893 \mathrm{~m}$ \\
\hline & 3 & $18^{\circ} 04^{\prime} 54.8^{\prime \prime} \mathrm{S}, 43^{\circ} 20^{\prime} 49.6^{\prime \prime} \mathrm{W}$ & $889 m$ \\
\hline & 4 & $18^{\circ} 04^{\prime} 55.0^{\prime \prime} \mathrm{S}, 43^{\circ} 20^{\prime} 51.3^{\prime \prime} \mathrm{W}$ & $893 \mathrm{~m}$ \\
\hline & 5 & $18^{\circ} 04^{\prime} 55.5^{\prime \prime} \mathrm{S}, 43^{\circ} 20^{\prime} 52.7^{\prime \prime} \mathrm{W}$ & $892 \mathrm{~m}$ \\
\hline \multirow[t]{5}{*}{3} & 1 & $18^{\circ} 05^{\prime} 25.2^{\prime \prime} \mathrm{S}, 43^{\circ} 20^{\prime} 43.5^{\prime \prime} \mathrm{W}$ & $839 \mathrm{~m}$ \\
\hline & 2 & $18^{\circ} 05^{\prime} 24.7^{\prime \prime} \mathrm{S}, 43^{\circ} 20^{\prime} 45.0^{\prime \prime} \mathrm{W}$ & $893 \mathrm{~m}$ \\
\hline & 3 & $18^{\circ} 05^{\prime} 24.7^{\prime \prime} \mathrm{S}, 43^{\circ} 20^{\prime} 46.1^{\prime \prime} \mathrm{W}$ & $839 \mathrm{~m}$ \\
\hline & 4 & $18^{\circ} 05^{\prime} 24.8^{\prime \prime} \mathrm{S}, 43^{\circ} 20^{\prime} 47.0^{\prime \prime} \mathrm{W}$ & $840 \mathrm{~m}$ \\
\hline & 5 & $18^{\circ} 05^{\prime} 24.9^{\prime \prime} \mathrm{S}, 43^{\circ} 20^{\prime} 47.7^{\prime \prime} \mathrm{W}$ & $838 \mathrm{~m}$ \\
\hline \multirow[t]{5}{*}{4} & 1 & $18^{\circ} 06^{\prime} 09.9^{\prime \prime} \mathrm{S}, 43^{\circ} 20^{\prime} 44.3^{\prime \prime} \mathrm{W}$ & $854 \mathrm{~m}$ \\
\hline & 2 & $18^{\circ} 06^{\prime} 11.4^{\prime \prime} \mathrm{S}, 43^{\circ} 20^{\prime} 44.7^{\prime \prime} \mathrm{W}$ & $965 \mathrm{~m}$ \\
\hline & 3 & $18^{\circ} 06^{\prime} 12.8^{\prime \prime} \mathrm{S}, 43^{\circ} 20^{\prime} 45.5^{\prime \prime} \mathrm{W}$ & $945 \mathrm{~m}$ \\
\hline & 4 & $18^{\circ} 06^{\prime} 13.8^{\prime \prime} \mathrm{S}, 43^{\circ} 20^{\prime} 46.4^{\prime \prime} \mathrm{W}$ & $967 \mathrm{~m}$ \\
\hline & 5 & $18^{\circ} 06^{\prime} 15.1^{\prime \prime} \mathrm{S}, 43^{\circ} 20^{\prime} 47.2^{\prime \prime} \mathrm{W}$ & $966 \mathrm{~m}$ \\
\hline \multirow[t]{5}{*}{5} & 1 & $18^{\circ} 06^{\prime} 31.9^{\prime \prime} \mathrm{S}, 43^{\circ} 20^{\prime} 46.7^{\prime \prime} \mathrm{W}$ & $889 \mathrm{~m}$ \\
\hline & 2 & $18^{\circ} 06^{\prime} 32.9^{\prime \prime} \mathrm{S}, 43^{\circ} 20^{\prime} 47.6^{\prime \prime} \mathrm{W}$ & 899 m \\
\hline & 3 & $18^{\circ} 06^{\prime} 33.1^{\prime \prime} \mathrm{S}, 43^{\circ} 20^{\prime} 49.0^{\prime \prime} \mathrm{W}$ & $903 \mathrm{~m}$ \\
\hline & 4 & $18^{\circ} 06^{\prime} 31.4^{\prime \prime} \mathrm{S}, 43^{\circ} 20^{\prime} 49.4^{\prime \prime} \mathrm{W}$ & $896 \mathrm{~m}$ \\
\hline & 5 & $18^{\circ} 06^{\prime} 30.4^{\prime \prime} \mathrm{S}, 43^{\circ} 20^{\prime} 49.2^{\prime \prime} \mathrm{W}$ & $896 \mathrm{~m}$ \\
\hline
\end{tabular}

Table S2. Scores for habitat complexity from the visual method established by Coops \& Catling (1997).

\begin{tabular}{lcccc} 
& \multicolumn{3}{c}{ SCORE } \\
\cline { 2 - 5 } & Feature & $\mathbf{0}$ & $\mathbf{1}$ & $\mathbf{2}$ \\
\hline Tree canopy (\%) & 0 & $<30$ & $30-70$ & $>70$ \\
Shrub canopy (\%) & 0 & $<30$ & $30-70$ & $>70$ \\
Ground herbage (density and height in meters) & Sparce $(<0.5 \mathrm{~m})$ & Sparce $(>0.5 \mathrm{~m})$ & Dense $(<0.5 \mathrm{~m})$ & Dense $(>0.5 \mathrm{~m})$ \\
Logs, Rocks, debris etc. (\%) & 0 & $<30$ & $30-70$ & $>70$ \\
Moisture in the soil & Dry & Moist & Permanent water nearby & Wet \\
\hline
\end{tabular}

Table S3. Habitat complexity scores of varying comparative tree canopy cover, shrub canopy cover, ground herbage cover, amount of logs/rocks/debris, and moisture in the soil, following visual method (Coops \& Catling, 1997), in the sampling sites at Rio Preto State Park, Minas Gerais, Brazil.

\begin{tabular}{lcccccc}
\hline Point & Tree & Shrub & Herbage & Logs & Moisture & $\begin{array}{c}\text { Total } \\
\text { (habitat } \\
\text { complexity) }\end{array}$ \\
\hline Point 1.1 & 1 & 2 & 0 & 2 & 0 & 5 \\
Point 1.2 & 1 & 2 & 0 & 2 & 0 & 5 \\
Point 1.3 & 1 & 2 & 0 & 2 & 0 & 5 \\
Point 1.4 & 2 & 3 & 0 & 2 & 0 & 7 \\
Point 1.5 & 2 & 3 & 0 & 2 & 0 & 7 \\
Point 2.1 & 0 & 0 & 1 & 1 & 0 & 2 \\
Point 2.2 & 0 & 1 & 2 & 1 & 0 & 4 \\
Point 2.3 & 1 & 1 & 2 & 1 & 0 & 5 \\
Point 2.4 & 1 & 1 & 2 & 1 & 0 & 5 \\
Point 2.5 & 1 & 1 & 2 & 1 & 0 & 5 \\
Point 3.1 & 0 & 0 & 2 & 1 & 0 & 3 \\
Point 3.2 & 0 & 1 & 2 & 1 & 0 & 4 \\
Point 3.3 & 2 & 2 & 0 & 1 & 0 & 5 \\
\hline
\end{tabular}

\begin{tabular}{ccccccc}
\hline Point & Tree & Shrub & Herbage & Logs & Moisture & $\begin{array}{c}\text { Total } \\
\text { (habitat } \\
\text { complexity) }\end{array}$ \\
\hline Point 3.4 & 2 & 2 & 0 & 2 & 1 & 7 \\
Point 3.5 & 3 & 0 & 0 & 3 & 3 & 9 \\
Point 4.1 & 0 & 0 & 2 & 1 & 0 & 3 \\
Point 4.2 & 0 & 0 & 2 & 1 & 0 & 3 \\
Point 4.3 & 1 & 2 & 1 & 3 & 0 & 7 \\
Point 4.4 & 1 & 2 & 1 & 3 & 0 & 7 \\
Point 4.5 & 1 & 2 & 1 & 3 & 0 & 7 \\
Point 5.1 & 0 & 2 & 1 & 0 & 0 & 3 \\
Point 5.2 & 1 & 1 & 1 & 1 & 1 & 5 \\
Point 5.3 & 2 & 1 & 1 & 2 & 0 & 6 \\
Point 5.4 & 2 & 1 & 1 & 2 & 0 & 6 \\
Point 5.5 & 2 & 1 & 1 & 2 & 0 & 6 \\
\hline
\end{tabular}




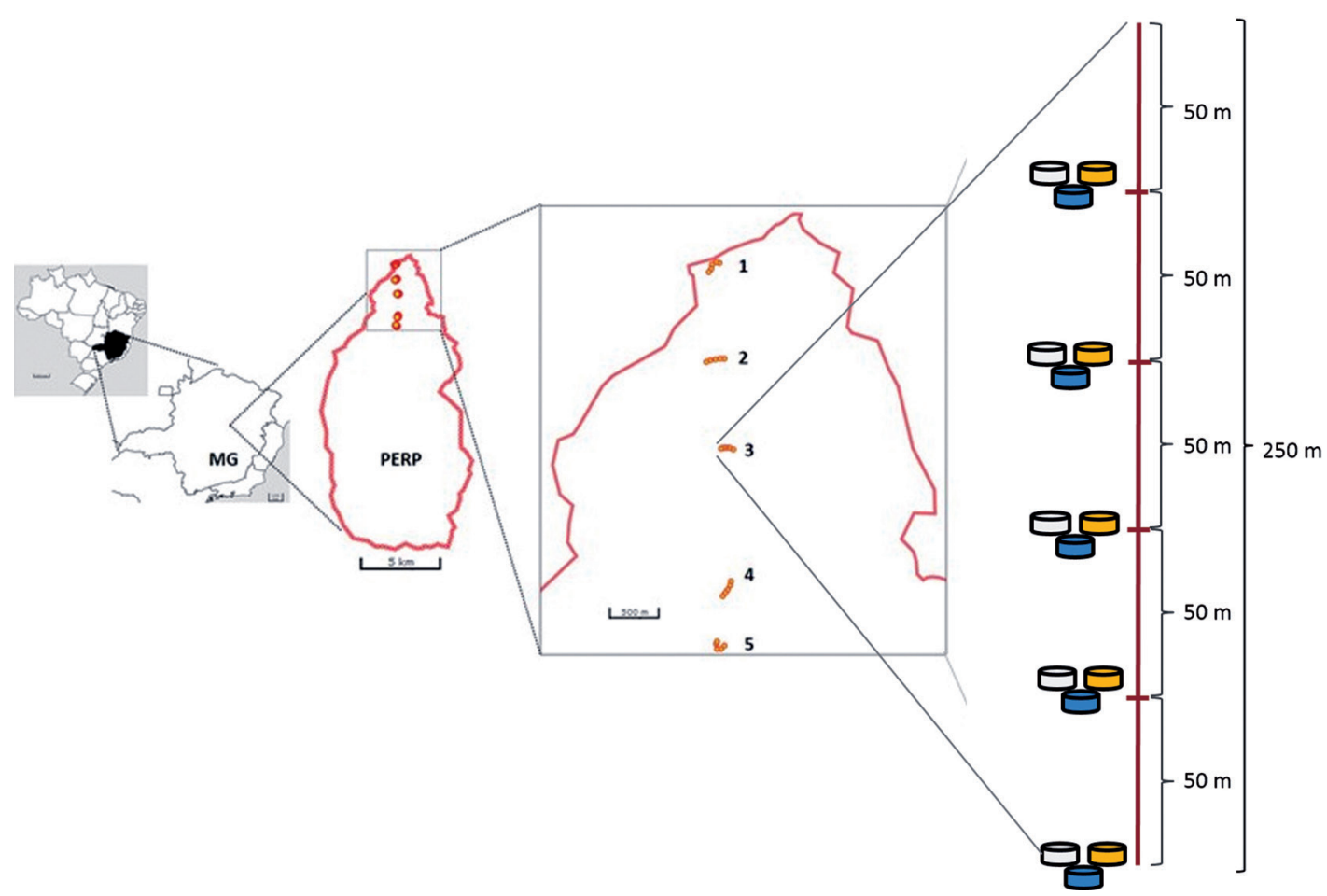

Figure S1. Map of the study site in the Rio Preto State Park, Minas Gerais, Brazil, and the schematic drawing illustrating the trail design (one of the 5 trails) and the position of the three colored traps (white, yellow and blue) in the trail.
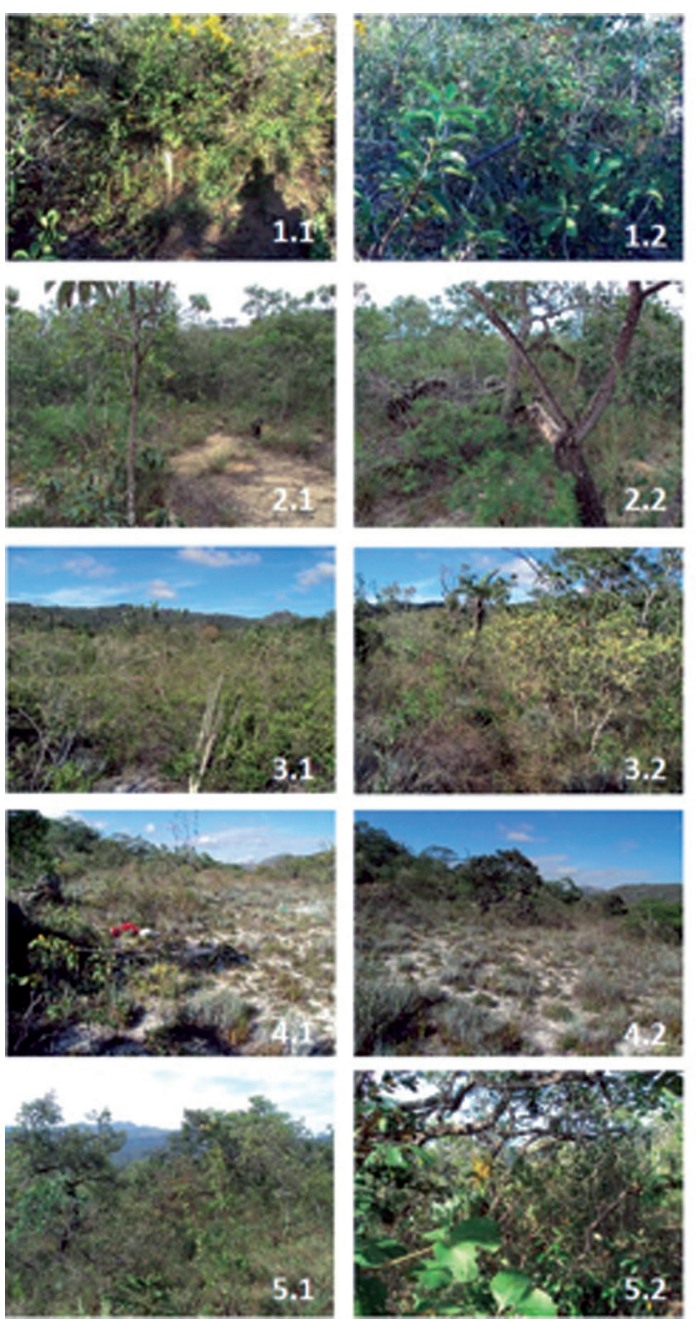
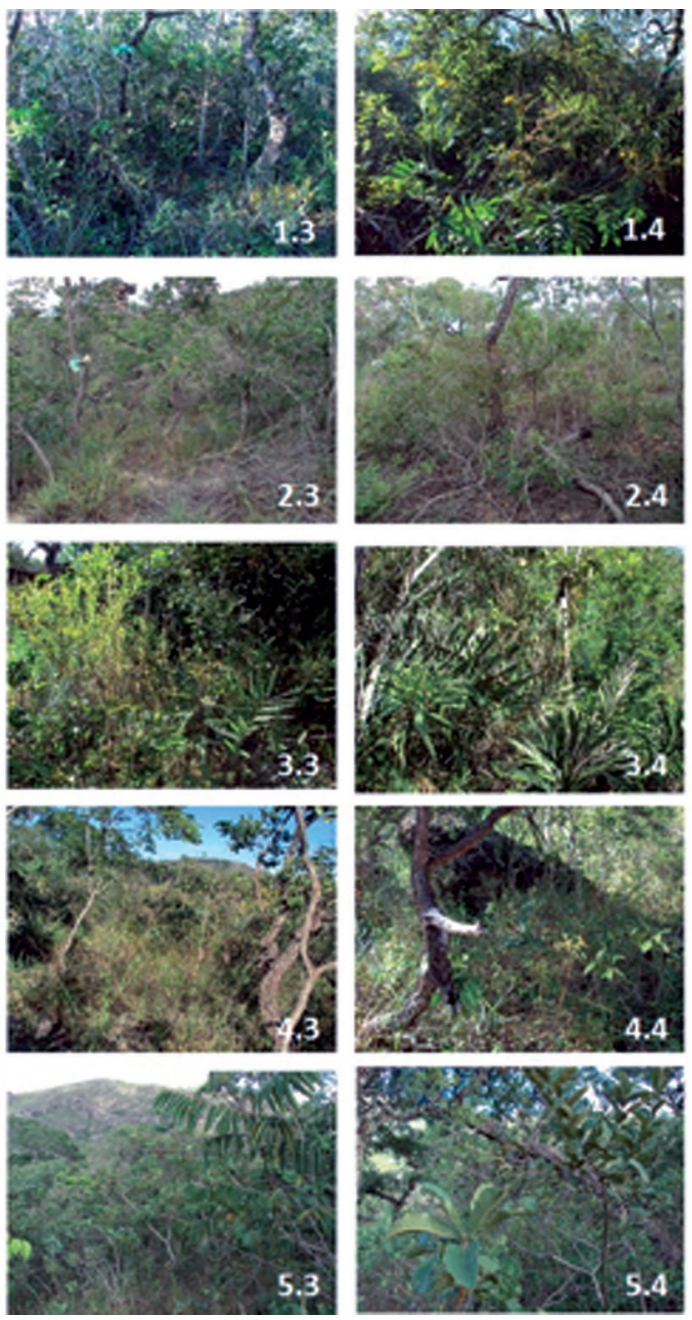
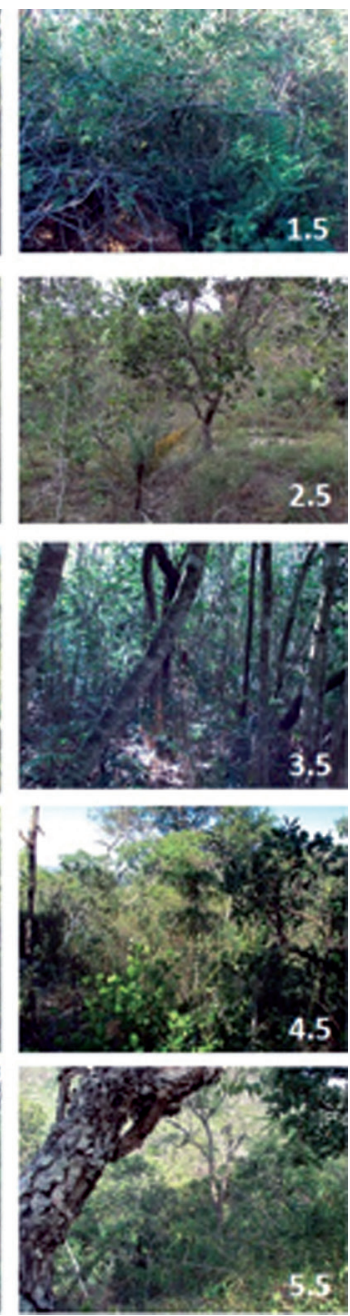

Figure S2. Habitat view of the point of each trail (trails in lines) used to collect bees using pan traps at Rio Preto State Park, Minas Gerais, Brazil. Pictures were taken in March 2014. 

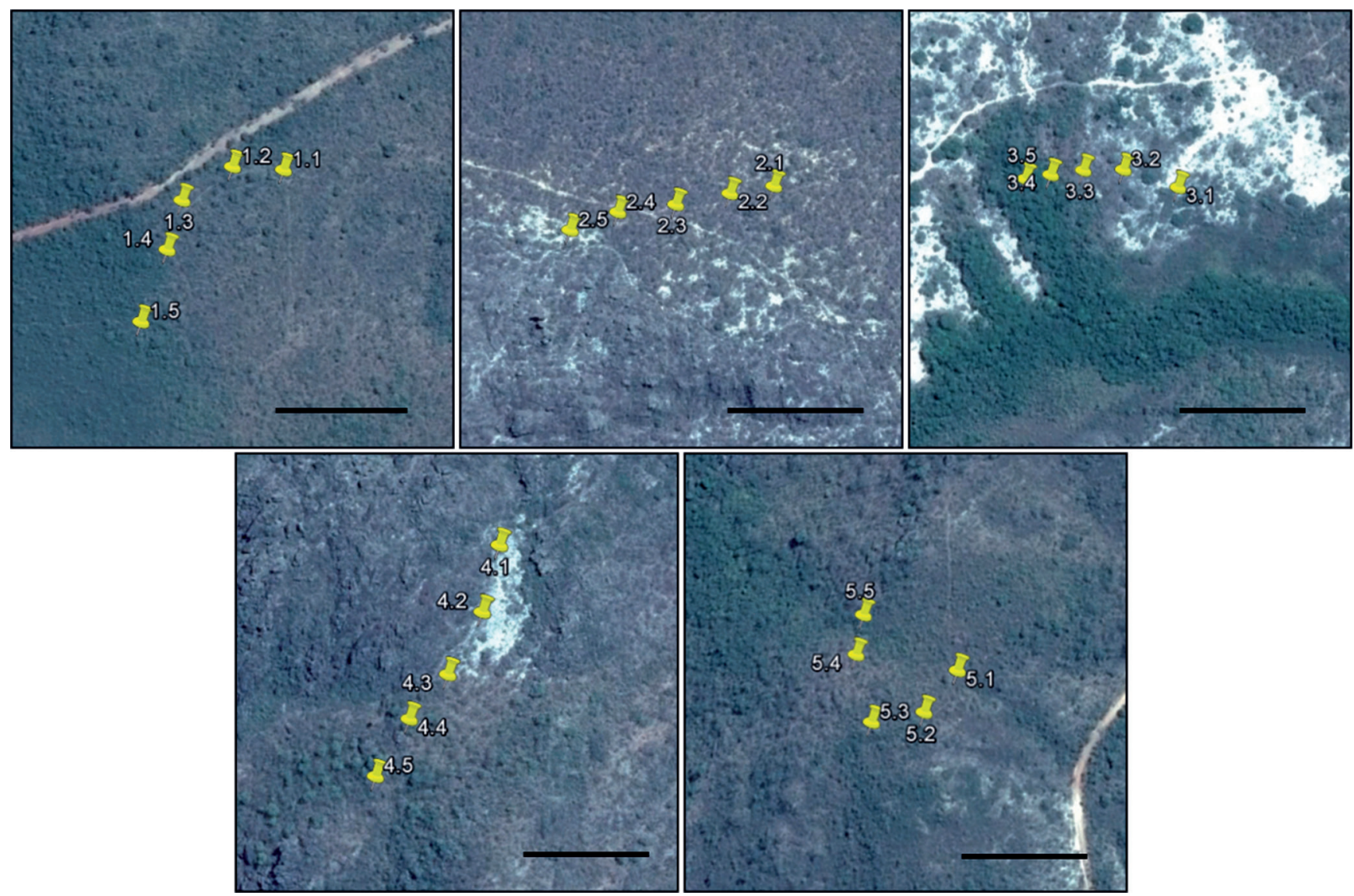

Figure S3. Landscape aerial images of the five trails and the five points at each trail used to collect bees using pan traps at Rio Preto State Park, Minas Gerais, Brazil. Satellite images from Google Earth. Scale bar $=100$ meters. 